Research Paper

\title{
Isolation of Dickeya dadantii strains from potato disease and biocontrol by their bacteriophages
}

\author{
Abbas Soleimani-Delfan, Zahra Etemadifar, Giti Emtiazi, Majid Bouzari \\ Department of Biology, Faculty of Sciences, University of Isfahan, Islamic Republic of Iran, Iran.
}

Submitted: June 11, 2014; Approved: December 28, 2014.

\begin{abstract}
One of the most economically important bacterial pathogens of plants and plant products is Dickeya dadantii. This bacterium causes soft rot disease in tubers and other parts of the potato and other plants of the Solanaceae family. The application of restricted host range bacteriophages as biocontrol agents has recently gained widespread interest. This study purposed to isolate the infectious agent of the potato and evaluate its biocontrol by bacteriophages. Two phytopathogenic strains were isolated from infected potatoes, identified based on biochemical and 16S rRNA gene sequencing, and submitted to GenBank as D. dadantii strain pis3 (accession no. HQ423668) and D. dadantii strain sip4 (accession no. HQ423669). Their bacteriophages were isolated from Caspian Sea water by enriching the water filtrate with $D$. dadantii strains as hosts using spot or overlay methods. On the basis of morphotypes, the isolated bacteriophages were identified as members of the Myoviridae and Siphoviridae families and could inhibit the growth of antibiotic resistant $D$. dadantii strains in culture medium. Moreover, in Dickeya infected plants treated with bacteriophage, no disease progression was detected. No significant difference was seen between phage-treated and control plants. Thus, isolated bacteriophages can be suggested for the biocontrol of plant disease caused by Dickeya strains.
\end{abstract}

Key words: Dickeya dadantii, soft rot, bacteriophage, antibiotic resistance, biocontrol.

\section{Introduction}

Each year, bacterial diseases cause significant loss of plant productions during cultivation and storage. Some members of the Enterobacteriaceae family, such as Dickeya dadantii sp. (Samson et al., 2005), formerly known as Erwinia chrysanthemi (Hauben et al., 1998), and Pectobacterium chrysanthemi, cause soft rot and black age disease in a wide range of crop plants such as sorghum, urn plant, sugarcane, rice, poinsettia, taro, nephthytis, carnation, African violet, pineapple, Aglaonema, philodendron, Dieffenbachia, orchid, cyclamen, tomato, Geranium, begonia, dahlia, corn, sweet potato, banana, gladiolus, potato, and carrot (Dickey, 1979; McFadden, 1958). These are Gram-negative, oxidase negative bacteria which grow at $39^{\circ} \mathrm{C}$. Samson et al. (2005) placed P. chrysanthemi in the genus Dickeya spp. and reclassified Erwinia (Pectobacterium) into the following six Dickeya species: $D$. chrysanthemi, D. paradisiacal, D. dadantii, D. dianthicola, D. dieffenbachiae, and D. zeae (Samson et al., 2005). In Finland, Pectobacterium and Dickeya sp. were isolated from infected potato stems and tubers and identified by sequencing as $P$. atrosepticum, $P$. carotovorum, and pathogens in the genus Dickeya. Furthermore, Dickeya strains were isolated from river water samples (Laurila et al., 2008). E. chrysanthemi disease on potato was reported in the 1980 s, and $D$. dadantii sp. disease on potato was reported in 2008 (Tsror et al., 2009). Several reports have indicated that $D$. dadantii could cause soft rot disease in potato seeds (Czajkowski et al., 2009; Ngadze et al., 2010). Hedjarood first isolated E. chrysanthemi on cyclamen in Iran in 1967.

The microbial agent of Erwinias soft rot disease is widespread in the environment; thus, controlling it is difficult. Several chemical compounds including copper, formaldehyde, 8-hydroxyquinoline, anthium dioxide, chlorine dioxide, gluytaraldehyde, benzalkonium chloride, cetalkonium chloride, and others are used to control Erwinias soft 
rot disease, but they are not very effective on this bacterium (Letal, 1977; Lund and Lyon, 1975; Wyatt and Lund, 1981). Potato diseases have been effectively controlled with antibiotics such as streptomycin, tetracycline, and vancomycin, but the development of antibiotic resistance in soil pathogens has limited their application (Gnanamanickam, 2007).

Recently, bacteriophages have been used as biocontrol agents to control pathogenic bacteria (Górski and Weber-Dabrowska, 2005; Jones et al., 2007; Smith et al., 1987; Verthé et al., 2004). The advantages of bacteriophages over other biocontrol agents include specificity to their bacterial hosts and non-pathogenicity for humans and animals (Czajkowski et al., 2013).

Not much information exists about $D$. dadantii or $E$. chrysanthemi lytic bacteriophages or their use in the biocontrol of plant disease. However, some studies have reported the use of bacteriophages against Erwinia and Dickeya spp. For example, Czajkowski et al. (2013) isolated lytic bacteriophages infecting Dickeya spp. Biovar 3, and used them to protect potato tuber tissue from symptoms of Dickeya infection. Fourteen bacteriophages of $E$. carotovora subsp. carotovora were isolated from samples of fertilizer solutions by Ravensdale et al. (2007), who were able to reduce the incidence of soft rot symptoms.

The current study aimed to isolate and identify new specific native bacteriophages against $D$. dadantii as potential agents for the biocontrol of plant disease caused by Dickeya.

\section{Materials and Methods}

\section{D. dadantii isolation}

Potato tuber and stem samples were collected from potato farms in Flavarjan, Isfahan, Iran (GPS coordinates of sampling locations include: 1: latitude: $32^{\circ} 33^{\prime} 33.26^{\prime \prime} \mathrm{N}$ and longitude: $51^{\circ} 29^{\prime} 11.10^{\prime \prime} \mathrm{E}$; 2 : latitude: $32^{\circ} 33^{\prime} 33.06^{\prime \prime} \mathrm{N}$ and longitude: $51^{\circ} 29^{\prime} 10.62^{\prime \prime} \mathrm{E}$; 3 : latitude: $32^{\circ} 32^{\prime} 29.53^{\prime \prime} \mathrm{N}$ and longitude: $51^{\circ} 30^{\prime} 6.33^{\prime \prime} \mathrm{E}$ ). Samples were stored at $4^{\circ} \mathrm{C}$ immediately after collection. To isolate bacteria, the external surface of the infected tubers and stems were disinfected in two steps: first with $70 \%$ ethanol, and then with $0.1 \% \mathrm{HgCl}_{2}$. Finally, they were rinsed $4-5$ times with sterile distilled water. Small amounts of tuber and stem samples were taken from the margin of healthy and diseased tissue and plated on Nutrient Agar (NA, Scharlou, Spain) and Brain Heart Infusion Agar (BHI, Merck, Germany) media (Laurila et al., 2008). After incubation at $28{ }^{\circ} \mathrm{C}$ for 24 hours, distinct colonies were purified by repeated subculturing on NA and BHI agar media.

\section{Biochemical and molecular identification of isolated bacteria}

Primary identification was performed according to Brenner et al. (2005). For molecular identification, the iso- lated bacteria were cultured on NB medium at $28^{\circ} \mathrm{C}$ for 48 hours. Genomic DNA was extracted by a commercial extraction kit (DNA extraction kit, Cinnagen, Iran) and amplified by two universal primers including RW01 as forward primer (5'AAC TGG AGG AAG GTG GGG AT3') and DG74 as reverse primer (5'AGG AGG TGA TCC AAC CGC A3') (TAG Copenhagen, Denmark) (Leong and Greisen, 1993). The nucleotides position of RW01 forward primer is 1172-1191 and of DG74 reverse primer is 1540-1522 of the DNA sequence coding for $16 \mathrm{~S}$ ribosomal RNA of E. coli (GenBank accession number: E05133). PCR mixture for amplification of the 16S rRNA gene contained $2.5 \mu \mathrm{L}$ 10X PCR buffer, $0.7 \mu \mathrm{L} \mathrm{MgCl}_{2}, 0.5 \mu \mathrm{LdNTP}$, $20 \mathrm{pM}$ of forward and reverse primers, $2 \mu \mathrm{L}$ DNA template, and $0.5 \mu \mathrm{L}$ DNA Taq polymerase (Cinnagen, Iran). PCR conditions were as follows: initial denaturation at $95^{\circ} \mathrm{C}$ for 5 min (1 cycle), denaturation at $94{ }^{\circ} \mathrm{C}$ for 45 seconds, annealing at $54{ }^{\circ} \mathrm{C}$ for 30 seconds, extension at $72{ }^{\circ} \mathrm{C}$ for 45 seconds in 30 cycles, and final extension at $72{ }^{\circ} \mathrm{C}$ for $5 \mathrm{~min}$. The PCR products (370 bp length) were sequenced by Macrogen, South Korea.

\section{Antibiotics susceptibility test}

The disk diffusion method was used for the antibiotic susceptibility test in Muller Hinton Agar (MHA, Merck, Germany). Zones of inhibition were measured ( $\mathrm{mm}$ ) and susceptibility was determined by standard tables of antibiogram (CLSI 2010).

\section{Isolation of bacteriophages}

In previous and parallel studies, it was hypothesized that Persian Gulf water and Caspian Sea water have great potential for bacteriophage isolation, because some rivers and agricultural wastes, such as biological matter (bacterial, viral, and fungal pathogens), sloped to the Caspian Sea shorelines. Based on this hypothesis, Caspian Sea water was used as a source for bacteriophage sampling. Samples of Caspian Sea water were collected from a depth of 50-100 cm along the shorelines of Kiashahr, Guilan, Iran and stored under sterile conditions at $4{ }^{\circ} \mathrm{C}$. GPS coordinates of sampling locations include: 1 : latitude: $37^{\circ} 26^{\prime} 27.33^{\prime \prime} \mathrm{N}$ and longitude: $49^{\circ} 57^{\prime} 54.45^{\prime \prime} \mathrm{E}$; 2 : latitude: $37^{\circ} 26^{\prime} 26.66^{\prime \prime} \mathrm{N}$ and longitude: $49^{\circ} 57^{\prime} 55.15^{\prime \prime} \mathrm{E}$; 3 : latitude: $37^{\circ} 26^{\prime} 25.22^{\prime \prime} \mathrm{N}$ and longitude: $49^{\circ} 57^{\prime} 50.44^{\prime \prime} \mathrm{E}$; 4: latitude: $37^{\circ} 28^{\prime} 16.64^{\prime \prime} \mathrm{N}$ and longitude: $49^{\circ} 56^{\prime} 22.07^{\prime \prime} \mathrm{E}$; 5: latitude: $37^{\circ} 28^{\prime} 12.59^{\prime \prime} \mathrm{N}$ and longitude: $49^{\circ} 56^{\prime} 26.38^{\prime \prime}$ E. Samples were centrifuged $(12,000 \mathrm{x} g, 10 \mathrm{~min})$, and the supernatant was filtrated through a 0.22 micrometer cellulose acetate membrane syringe filter (Orange Scientific, Belgium). Then, glycine buffer ( $1 \% \mathrm{w} / \mathrm{v}-$ Sigma, Germany) was added to the filtered samples for preservation of bacteriophages, and the samples were stored at $4{ }^{\circ} \mathrm{C}$. A loop full of isolated bacteria was cultured in BHI broth medium as host, then after 2 hours pre-incubation, $1,000 \mu \mathrm{L}$ of phage-filtered sample was added and incubated at $28^{\circ} \mathrm{C}$ overnight. The bacterial cul- 
ture was then centrifuged at $12,000 \mathrm{x} g$ for $10 \mathrm{~min}$ and filtrated through $0.22 \mu$ filters (Gill et al., 2003; Ritchie and Klos, 1977). The soft-agar overlayer method was used for bacteriophage plaque formation (Clokie and Kropinski, 2009). Diluted bacteriophage filtrates were added to a tube of warm overlay NA medium ( $0.7 \%)$, enriched with $100 \mu \mathrm{L}$ of $D$. dadantii bacterial culture as host, plated on sublayer (NA medium), and incubated at $28{ }^{\circ} \mathrm{C}$ for 12 hours. This procedure was repeated 5-7 times to purify phages isolated from single plaques.

\section{Preparation of high titer bacteriophage}

Phages were propagated on isolated $D$. dadantii strains. First the phage originating from a single plaque was mass streaked on the lawn of the propagating bacterium on a soft NA $(0.7 \%)$ with a sterile toothpick. Following overnight incubation at $28^{\circ} \mathrm{C}$, the phages were eluted with $5 \mathrm{~mL}$ sterilized glycine buffer (1\%), and the resulting phage suspensions $\left(10^{10} \mathrm{PFU} / \mathrm{mL}\right)$ were used to prepare high-titer suspensions as follows: $100 \mathrm{~mL}$ Nutrient Broth (NB) medium (Gill et al., 2003; Ritchie and Klos, 1977) was inoculated by the propagating bacterium to $10^{8}$ cells $/ \mathrm{mL}$ final concentrations and $10^{7} \mathrm{PFU} / \mathrm{mL}$ from phage. After a 15-min preincubation time, the cultures were placed in a rotary shaker $(50 \mathrm{rpm})$ for overnight incubation at $28^{\circ} \mathrm{C}$. Bacterial debris was eliminated from the lysates by further centrifugation (12000x $g, 10 \mathrm{~min}$ ), then either glycine buffer $(1 \% \mathrm{v} / \mathrm{w})$ or chloroform-treated buffer was added for preservation of the bacteriophages, and they were stored at $4{ }^{\circ} \mathrm{C}$. All controls were stored under the same conditions in sterile double-distilled water without using glycine or chloroform. Bacteriophages were titrated using the direct plate plaque assay based on the method introduced by Mazzocco et al. (2009) and calculated as follows:

Average number of plaques $\mathrm{x} 5 \mathrm{x}$ reciprocal of counted dilution $=\mathrm{PFU} / \mathrm{mL}$

\section{Growth curve of isolated Dickeya with bacteriophage}

The purified colonies of isolated strains were cultured in NB medium $\left(28^{\circ} \mathrm{C}, 120 \mathrm{rpm}\right.$, overnight). Two percent $(\mathrm{v} / \mathrm{v})$ of the enriched bacterial culture was inoculated to $250 \mathrm{~mL}$ NB medium in $1 \mathrm{~L}$ flasks and incubated on a rotary shaker (120 rpm) for 30 hours. The optical densities of culture were measured at 2-hour intervals. The experiment was repeated using the same conditions except that the bacteriophage suspension ( $3 \times 10^{9} \mathrm{PFU} / \mathrm{mL}$ ) was added to the bacterial culture for analysis of bacterial lysis activity of the isolated phages.

\section{Electron microscopy}

High titer bacteriophage suspensions were transferred onto copper-coated grids with formvare for $2 \mathrm{~min}$. The additional suspension was dried using Watman filter paper, and the grade was stained by $1 \%$ uranyl acetate for
30 seconds. The grids were viewed using Philips CM10 transmission electron microscopy.

\section{Antibacterial effects of phages on Dickeya dadantii-infected Geranium spp. at laboratory scale}

The two Siphoviridae- and Myoviridae-related phages were used separately to control $D$. dadantii sip4 pathogenicity in cranesbill (Geranium spp.). Bacterial suspension grown in an NB medium at logarithmic growth phase $\left(A_{600 n m}=0.6\right)$ was washed with sterile deionized water and resuspended in the same water to $5 \times 10^{8}$ cells $/ \mathrm{mL}$. Then it was used to create lesions in Geranium being sprayed onto leaves (group 1). Similar to group 1 and two days before spraying the bacterial suspension onto the leaves, $3 \times 10^{9} \mathrm{PFU} / \mathrm{mL}$ of Siphoviridae- and Myoviridaerelated bacteriophages were sprayed onto leaves in experimental group 2. Plants in group 3 were tested without any bacteria or bacteriophages treatments. The 3 groups of plants were stored in greenhouse conditions at $32{ }^{\circ} \mathrm{C}$ and $80-90 \%$ humidity. This experimental procedure was repeated nine times under the same conditions, and the results were examined using Mann-Whitney U and KruskalWallis tests. All statistical analyses were carried out at $\alpha=0.05$ significance level.

\section{Results}

\section{Dickeya dadantii isolation and identification}

The bacteria isolated from infected potatoes (Solanum tuberosum) were identified by biochemical tests for the Erwinia group (Table 1). In molecular analyses, the amplified 16S rRNA genes of two isolated bacterial strains

Table 1 - The results of morphological and biochemical characteristics of Dickeya spp.

\begin{tabular}{lcc}
\hline Test & D. dadantii pis3 & D. dadantii sip4 \\
\hline Shape & $\mathrm{R}$ & $\mathrm{R}$ \\
Motility & + & + \\
Aerobic growth & + & + \\
Anaerobic growth & - & + - \\
Catalase & + & + \\
Oxidase & - & - \\
Pink pigment & - & - \\
Growth at $36{ }^{\circ} \mathrm{C}$ & + & + \\
Urease & - & - \\
Pectate lysate & + & + \\
Gelatin hydrolysis & + & + \\
Growth in $5 \% \mathrm{NaCl}$ & + & + \\
Lesitinase & + & - \\
Erythromycin* & + & - \\
\hline
\end{tabular}

R: Rod shape; (+/-): not clear; *sensitivity to erythromycin; (+) positive; (-) negative. 
were identified using the megablast program of NCBI (www.NCBI.nlm.nih.gov). Due to the high homology of the amplified ribosomal DNA sequences with $D$. dadantii, two bacterial strains isolated in this experiment were submitted to GenBank as D. dadantii pis3 (GenBank accession number HQ423668) and D. dadantii sip4 (GenBank accession number HQ423669).

\section{Antibiotic sensitivity}

The results of the antibiotic susceptibility test for isolated Dickeya are shown in Table 2. The isolated strain pis3 was sensitive to amikacin, siprofloxacillin, and oxytetracyclin. Strain pis3 was also sensitive to erythromycin, but strain sip4 was resistant (Table 2).

\section{Isolation of bacteriophages and assessment of plaque morphology}

The bacteriophage produced two various types of plaque morphology on the $D$. dadantii lawn culture: large plaques with $5 \mathrm{~mm}$ diameters and opaque halos in their margins and small plaques with 1-2 $\mathrm{mm}$ diameters and opaque halos (Figure 1).

\section{Growth curve of isolated Dickeya with bacteriophage}

The growth rates of the isolated bacteria with and without bacteriophage are shown in Figure 2. In the presence of bacteriophage, bacteria growth was inhibited for 17 hours, after which, it was initiated and increased.

\section{Transmission electron microscopy}

Two types of bacteriophage were identified based on their morphology. Bacteriophages with regular hexagonal head of 90-100 nm length, $25-30 \mathrm{~nm}$ width, and $120 \mathrm{~nm}$ long tails were identified as the Siphoviridae family (Figu-

Table 2 - Antibiotic sensitivity test of Dickeya dadantii strains pis3 and sip4.

\begin{tabular}{lccc}
\hline \multirow{2}{*}{ Antibiotics } & g per disc & \multicolumn{2}{c}{ Sensitivity } \\
\cline { 3 - 4 } & & Strain pis3 & Strain sip4 \\
\hline Oxytetracyclin & 30 & $\mathrm{~S}$ & $\mathrm{I}$ \\
Carbenicillin & 100 & $\mathrm{R}$ & $\mathrm{R}$ \\
Tobramycine & 10 & $\mathrm{R}$ & $\mathrm{R}$ \\
Erythromycin & 15 & $\mathrm{~S}$ & $\mathrm{R}$ \\
Nalidixic acid & 30 & $\mathrm{I}$ & $\mathrm{S}$ \\
Vankomycin & 30 & $\mathrm{R}$ & $\mathrm{R}$ \\
Cloxacillin & 5 & $\mathrm{R}$ & $\mathrm{R}$ \\
Chloramphonicle & 30 & $\mathrm{I}$ & $\mathrm{R}$ \\
Clindamycin & 2 & $\mathrm{R}$ & $\mathrm{R}$ \\
Ceftisoxim & 30 & $\mathrm{R}$ & $\mathrm{R}$ \\
Siprofloxacillin & 5 & $\mathrm{~S}$ & $\mathrm{I}$ \\
Amikacin & 30 & $\mathrm{~S}$ & $\mathrm{~S}$ \\
\hline
\end{tabular}

$\mathrm{R}=$ Resistant; $\mathrm{I}=$ Intermediate; $\mathrm{S}=$ Sensitive. re 3a) and bacteriophages with hexagonal heads (approximately $100 \mathrm{~nm}$ length and 50-60 nm width) and 90-100 nm long tails were identified as the Myoviridae family (Figure $3 b)$.

\section{Bacteriophage enumeration in preservative buffer}

The obtained phage suspensions had titers of up to $1.9 \times 10^{10} \mathrm{PFU} / \mathrm{mL}$. The bacteriophage was enumerated both pre- and post-incubation at $4{ }^{\circ} \mathrm{C}$ for 8 months. All results indicated that glycine could preserve bacteriophage particles for up to 8 months at $4{ }^{\circ} \mathrm{C}$ in good conditions with no apparent change in phage titer, while for phages preserved with chloroform-treated buffer, and double distilled water, bacteriophage titration decreased (Table 3).

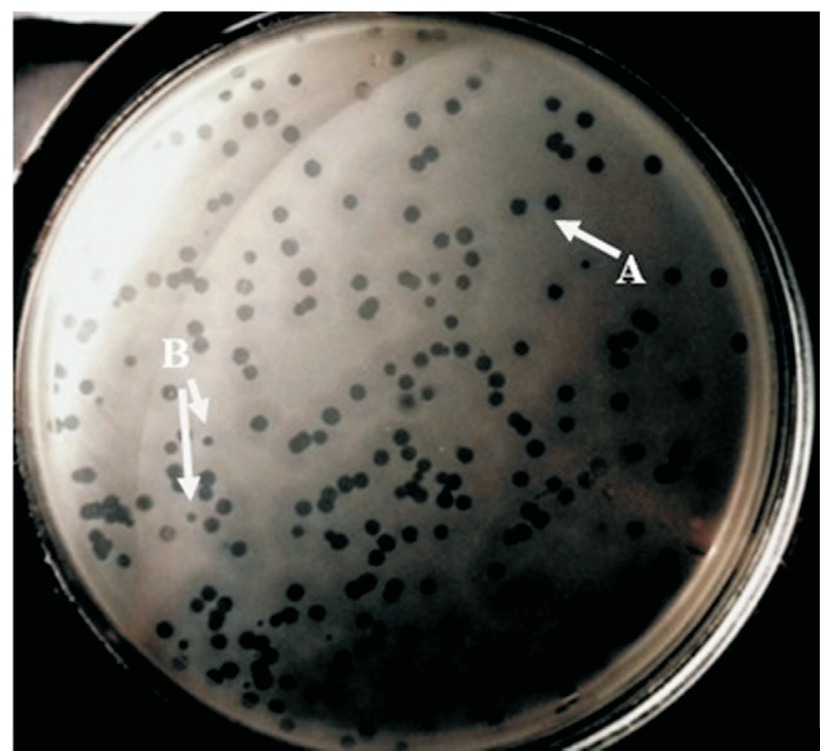

Figure 1 - Plaques formation in agar medium. The isolated Dickeya propagated on soft nutrient yeast agar medium, and the phage suspension spread on the medium. A) plaques up to 4-5 millimeter diameter (Myoviridae phage), and B) plaque up to 2-3 millimeter diameter (Siphoviridae phage).

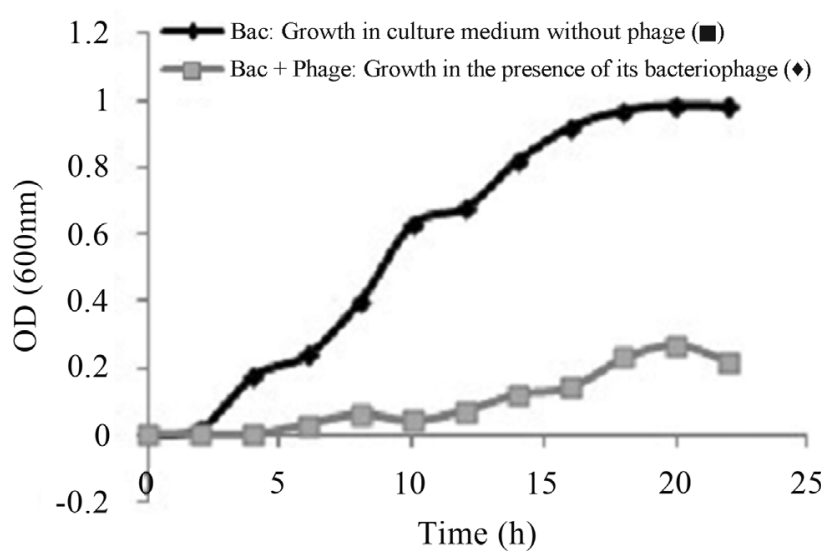

Figure 2 - Growth curve of Dickeya dadantii. 
Table 3 - Titers of two isolated bacteriophages $(\mathrm{PFU} / \mathrm{mL})$ in glycine solution and pure water (DDW).

\begin{tabular}{lcccc}
\hline Isolated bacteriophage & Solution & pre incubation & After 4 months & After 8 months \\
\hline Myoviridae & Glycine & $2.2 \times 10^{10}$ & $2.1 \times 10^{10}$ & $1.97 \times 10^{10}$ \\
Siphoviridae & DDW & $2.2 \times 10^{10}$ & $0.5 \times 10^{10}$ & - \\
& Glycine & $1.77 \times 10^{10}$ & $1.68 \times 10^{10}$ & $1.63 \times 10^{10}$ \\
& DDW & $1.77 \times 10^{10}$ & $0.65 \times 10^{10}$ & $\leq 0.1 \times 10^{10}$ \\
\hline
\end{tabular}

(-) Without plaque, DDW (double distilled water).
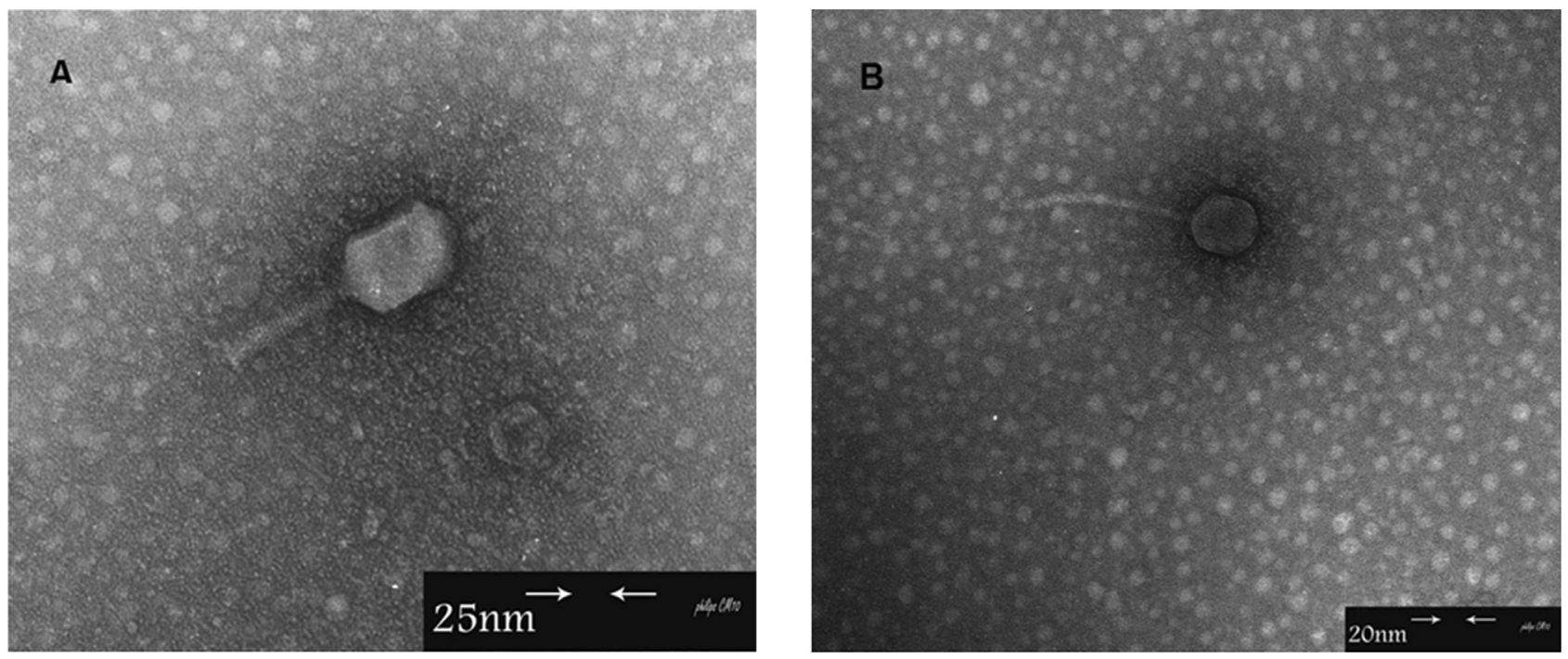

Figure 3 - Electron micrograph of Dickeya dadantii phages: (a) Myoviridae family, (b) Siphoviridae family.

\section{D. dadantii pathogenesis reduced by its bacteriophage}

After 5 days of incubation, Geranium spp. with the bacterial suspension in group 1 showed several symptoms of lesions, such as chlorosis and necrosis on leaves and stems. After 5 days, the leaves had rotted, and plants infected with $D$. dadantii sip4 were completely rotten. In the second group of plants that were treated with bacterial and bacteriophage suspensions, only 3 of the 27 tested plants treated with Myoviridae-related bacteriophage faded completely after five days. Other treated geraniums in this group grew without any symptoms of disease. Data was analyzed with the Kruskal-Wallis test, and four groups within the groups were significantly different $(\mathrm{p}=0.00)$. Moreover, the differences between bacteria/phages $(p=0.00)$, bacteria/control $(p=0.00)$, bacteria/phage siph $(p=0.00)$ were statistically significant; between phage/control treatment, phage myo/control $(\mathrm{p}=0.258)$, phage myo/phage siph $(p=0.863)$, and control/phage siph $(p=0.222)$, the data for phages and control treatment showed no statistical differences (Figure 4).

\section{Discussion}

D. dadantii causes soft rot disease in plants of the Solanaceae family, including the potato (Czajkowski et al., 2009; Laurila et al., 2008; Ngadze et al., 2010; Tsror et al., 2009). In the current study, two strains of $D$. dadantii were isolated from infected potato tissue for the first time in Iran. Also isolated were two lytic bacteriophages of the Myoviridae and Siphoviridae families from water of the Caspian Sea, located in northern Iran, against isolated strains of $D$. dadantii from infected potatoes from central Iran (Isfahan province). Adriaenssens et al. identified two bacteriophages, LIMEstone 1 and LIMEstone 2, against $D$. solani belonging to Myoviridae which had icosahedral heads of $91.4 \mathrm{~nm}$ and tail dimensions of $113.8 \times 17 \mathrm{~nm}$ (Adriaenssens et al., 2012).

Schenabel and Jones (2001) reported five bacteriophages of E. amylovora isolated from apple orchards that belonged to Myoviridae. Czajkowski et al. isolated nine bacteriophages infecting Dickeya spp. biovar 3 from soil of distinct geographical locations in Poland, which were morphologically related to the order Caudovirales, family Myoviridae (Czajkowski et al., 2013). Gill et al. isolated 42 bacteriophages against $E$. amylovora from pear and apple 


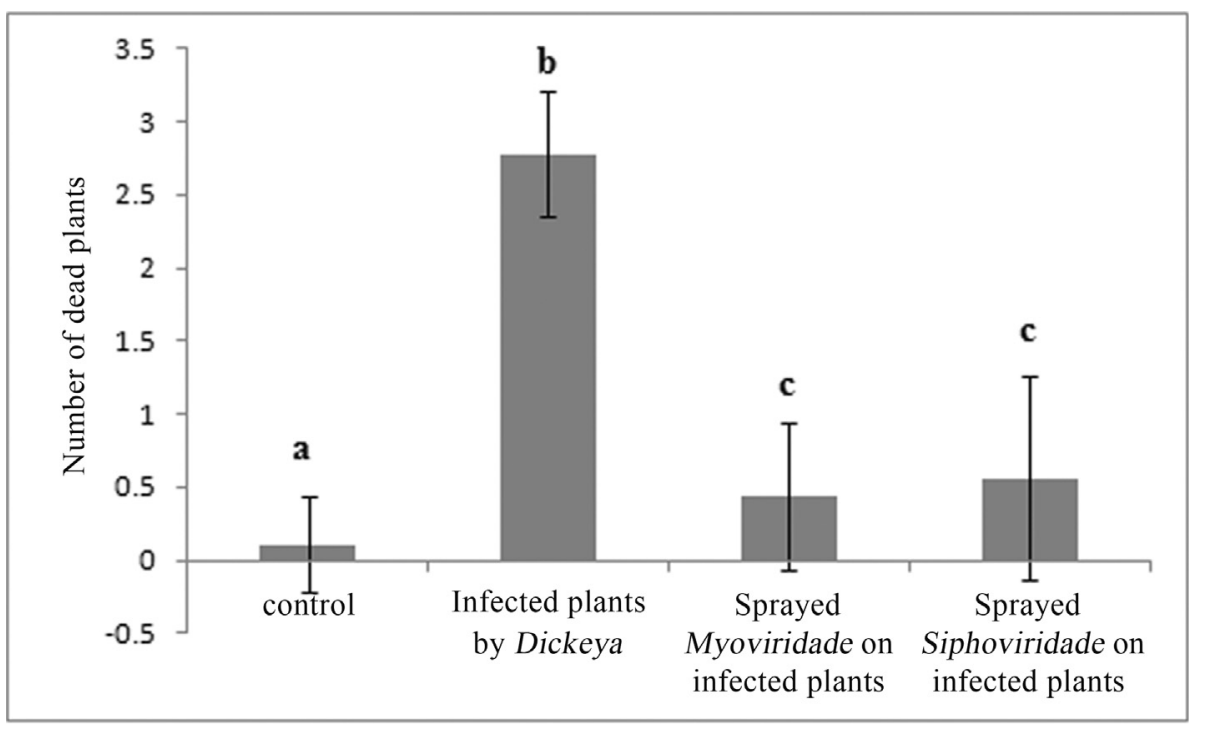

Figure 4 - Cranesbill (Geranium spp.) plants infected by $5 \times 10^{8}$ cells $/ \mathrm{mL}$ of Dickeya dadantii sip4 and treated by $3 \times 10^{9} \mathrm{PFU} / \mathrm{mL}$ of Siphoviridae and Myoviridae related bacteriophages, plant in control group treated with DDW, and plants in bacteria group inoculated with $5 \times 10^{8}$ cells $/ \mathrm{mL}$ of Dickeya dadantii sip4.

that were from the Myoviridae family and were smaller than ones isolated in the current study (Gill et al., 2003). Only Kishko et al. seem to have reported the isolation of bacteriophages of Siphoviridae infecting E. carotovora (Kishko et al., 1983). This study isolated two members of Myoviridae and Siphoviridae bacteriophage infecting $D$. dadantii strains from rotting potato tubers for the first time in Iran.

In many studies the use of a few drops of chloroform in the buffer is suggested for the preservation of various bacteriophages at $4{ }^{\circ} \mathrm{C}$ (Clokie and Kropinski, 2009). The isolated phages that were identified as the Siphoviridae and Myoviridae families were unstable in chloroform. Therefore, for bacteriophage preservation, the isolated phages in this study were found to be stable in the solutions made with $1 \%(\mathrm{w} / \mathrm{v})$ glycine buffer rather than in buffer solutions with chloroform or in double distilled water. Glycine buffer could preserve phages with no significant change in the titer for up to eight months at $4{ }^{\circ} \mathrm{C}$.

Isolated lytic bacteriophages from the Caspian Sea samples were able to significantly reduce population of isolated Dickeya strains from central Iran in the culture media. In first phage titration of Caspian Sea water samples without phage enrichment, approximately 271 plaque units were observed on Dickeya strains. This massive plaque forming unit (PFU) of bacteriophage indicated that Caspian Sea water has great potential for phage therapy in this case. This observation indicates that the sampling regions (Guilan province and Kiashahr farmlands and rivers) are contaminated and infected with Dickeya spp. or other related phytopathogens.

Erwinia cannot be controlled by specific bactericides (like other phytopathogenic bacteria) (Gnanamanickam,
2007). The incidence of antibiotic resistance may increase among bacteria due to the use of antibiotics in treating plant diseases, and this may be an origin of antibiotic-resistance genes in agroecosystems and the transfer of these genes to human pathogenic bacteria. Other compounds such as copper- and sulfur-containing formulations are not very effective and cause environmental pollution (Gnanamanickam, 2007). In this study, the isolated bacteria were resistant to most antibiotics but were lysed completely by isolated bacteriophages; so, these bacteriophages are capable of biocontrolling plant disease caused by specific bacterial hosts.

Data from this study showed that $D$. dadantii strains caused necrosis, soft rot, and black age disease in Geranium spp. in a few days. However, the Dickeya-infected plants (Geranium spp.) which were treated with specific bacteriophages showed no symptoms of disease in comparison with infected non-treated plants. Regarding the resistance of the isolated bacteria to most broad spectrum antibiotics, the use of the bacteriophages for controlling potato disease could be more effective in eliminating the targeted bacterial pathogens. Moreover, phages could be safe substitutes for toxic chemical agents such as antibiotics or other bactericidal agents in the control of plant diseases. However, more research with plants is needed to extend the findings of the current study regarding the application of biocontrol agents such as bacteriophage in agroecosystems.

\section{Acknowledgments}

The authors would like to express thanks to the University of Isfahan for financial support of this work. 


\section{References}

Adriaenssens EM, Van Vaerenbergh J, Vandenheuvel D et al. (2012) T4-related bacteriophage LIMEstone isolates for the control of soft rot on potato caused by Dickeya solani. PloS one $7: \mathrm{e} 33227$.

Brenner DJ, Krieg NR, Staley JT et al. (2005) Bergey's Manual of Systematic Bacteriology. 2nd ed. vol. 2 (The Proteobacteria), part B (The Gammaproteobacteria), Springer, New York, pp. 721-730.

Clokie M, Kropinski A (2009) Bacteriophages: Methods and Protocols: Isolation, Characterization, and Interactions. Humana Pr Inc pp 69-76.

CLSI (2010) M100-S20. Performance Standards for Antimicrobial Susceptibility Testing: 20th Informational supplement. Clinical and Laboratory Standards Institute Wayne.

Czajkowski R, Grabe GJ, van der Wolf JM (2009) Distribution of Dickeya spp. and Pectobacterium carotovorum subsp. carotovorum in naturally infected seed potatoes. Eur J Plant Pathol 125:263-275.

Czajkowski R, Ozymko Z, Lojkowska E (2013) Isolation and characterization of novel soilborne lytic bacteriophages infecting Dickeya spp. biovar 3 ('D. solani'). Plant Pathol 63:758-772.

Dickey RS (1979) Erwinia chrysanthemi: a comparative study of phenotypic properties of strains from several hosts and other Erwinia species. Phytopathology 69:324-329.

Gill J, Svircev A, Smith R et al. (2003) Bacteriophages of Erwinia amylovora. Appl Environ Microbiol 69:2133.

Gnanamanickam SS (2007) Plant-associated bacteria. Springer Verlag, Dordrecht, The Netherlands, pp 423-505.

Górski A, Weber-Dabrowska B (2005) The potential role of endogenous bacteriophages in controlling invading pathogens. Cell Mol Life Sci 62:511-519.

Hauben L, Moore E, Vauterin L et al. (1998) Phylogenetic position of phytopathogens within the Enterobacteriaceae. Syst Appl Microbiol 21:384-397.

Jones J, Jackson L, Balogh B et al. (2007) Bacteriophages for plant disease control. Phytopathology 45:245-262.

Kishko Y, Ruban V, Tovkach F et al. (1983) Structure of Erwinia carotovora temperate bacteriophage 59 and its DNA. J Virol 46:1018.

Laurila J, Ahola V, Lehtinen A et al. (2008) Characterization of Dickeya strains isolatedfrom potato and river water samples in Finland. Eur J Plant Pathol 122:213-225.

Leong DU, Greisen KS (1993) PCR detection of bacteria found in cerebrospinal fluid. In: Persing, D.H. (ed). Diagnostic Molecular Microbiology: Principles and Applications. American Society for Microbiology, Washington, DC, pp 300306.
Letal J (1977) Efficacy of disinfestants against potato ring rot and blackleg bacteria. Am J Potato Res 54:405-409.

Lund B, Lyon G (1975) Detection of inhibitions of Erwinia carotovora and E. herbicola on thin-layer chromatogram. J Chromatogr A 110:193-196.

Mazzocco A, Waddell TE, Lingohr E et al. (2009) Enumeration of bacteriophages by the direct plating plaque assay. Mol Biol 501:77-80.

McFadden LA (1958) Bacterial blight of Chrysanthemum. In: Proc. Florida State Hort. Soc 71:419-425.

Ngadze E, Coutinho T, van der Waals J (2010) First Report of Soft Rot of Potatoes Caused by Dickeyadadantii in Zimbabwe. Plant Dis 94:1263-1263.

Ravensdale M, Blom T, Gracia-Garza J et al. (2007) Bacteriophages and the control of Erwinia carotovora subsp. carotovora. Can J Plant Pathol 29:121-130.

Ritchie D, Klos E (1977) Isolation of Erwinia amylovora bacteriophage from aerial parts of apple trees. Phytopathology 67:101-104.

Samson R, Legendre J, Christen R et al. (2005) Transfer of Pectobacterium chrysanthemi (Burkholder et al., 1953) Brenner et al., 1973 and Brenneria paradisiaca to the genus Dickeya gen. nov. as Dickeya chrysanthemi comb. nov. and Dickeya paradisiaca comb. nov. and delineation of four novel species, Dickeya dadantii sp. nov., Dickeya dianthicola sp. nov., Dickeya dieffenbachiae sp. nov. and Dickeya zeae sp. nov. Int J Syst Evol Microbiol 55:14151427.

Schnabel E, Jones A (2001) Isolation and characterization of five Erwinia amylovora bacteriophages and assessment of phage resistance in strains of Erwinia amylovora. Appl Environ Microbiol 67:59-64.

Smith HW, Huggins MB, Shaw KM (1987) The control of experimental Escherichia coli diarrhoea in calves by means of bacteriophages. J Gen Microbiol 133:1111-1126.

Tsror L, Erlich O, Lebiush S et al. (2009) Assessment of recent outbreaks of Dickeya sp.(syn. Erwinia chrysanthemi) slow wilt in potato crops in Israel. Eur J Plant Pathol 123:311320.

Verthé K, Possemiers S, Boon N et al. (2004) Stability and activity of anEnterobacter aerogenes-specific bacteriophage under simulated gastro-intestinal conditions. Appl Microbiol Biotechnol 65:465-472.

Wyatt G, Lund B (1981) The effect of antibacterial products on bacterial soft rot of potatoes. Potato Res 24:315-329.

Associate Editor: Fernando Dini Andreote

All the content of the journal, except where otherwise noted, is licensed under a Creative Commons License CC BY-NC. 